\title{
The "Steppe Belt" of stockbreeding cultures in Eurasia during the Early Metal Age
}

\author{
El “Cinturón estepario" de culturas ganaderas en Eurasia durante la Primera Edad \\ del Metal
}

Evgeny Chernykh (*)

\begin{abstract}
The stock-breeding cultures of the Eurasian "steppe belt" covered approximately 7-8 million square $\mathrm{km}^{2}$ from the Lower Danube in the West to Manchuria in the East (a distance of more than $8000 \mathrm{~km}$ ). The initial formation of the "steppe belt'cultures coincided with the flourishing of the Carpatho-Balkan metallurgical province (V millennium BC). These cultures developed during the span of the Circumpontic metallurgical province (IV-III millennium $B C$ ). Their maturation coincided with the activity of the various centers of the giant Eurasian and East-Asian metallurgical provinces (II millennium BC). The influence of these stock-breeding nomadic cultures on the historical processes of Eurasian peoples was extremely strong. The collapse of the "steppe belt" occurred as late as the XVIII ${ }^{\text {th }}$ and XIX ${ }^{\text {th }}$ centuries AD.
\end{abstract}

\section{RESUMEN}

Las culturas ganaderas del "cinturón estepario" de Eurasia cubrieron aproximadamente 7-8 millones de $\mathrm{km}^{2}$, entre el bajo Danubio al oeste y Manchuria al este (una distancia de más de $8000 \mathrm{~km}$ ). La formación inicial de estas culturas coincide con el florecimiento de la provincia metalúrgica Cárpato-Balcánica (V milenio AC). Estas culturas se desarrollaron durante la provincia metalúrgica Circumpóntica (IV-III milenios AC). Su madurez coincide con la actividad de varios centros de las grandes provincias metalúrgicas Euroasiática y del Asia oriental (II milenio AC). La influencia de estas culturas ganaderas en los procesos históricos de las gentes de Eurasia fue muy intensa. El colapso de este "cinturón

(*) Russian Academy of Sciences, Institute of Archaeology, Laboratory of Natural Scientific Methods. Dm. Ulyanova 19.117086 Moscow. Russia. Email: archmetal@rambler.ru. The work is supported by RFBR project $08-06-0075$ and RFH project 08-01-00073a.

Recibido 22-X-2007; aceptado 6-II-2008. estepario" sucedió en una fecha tan tardía como los siglos XVIII- XIX AD.

Key words: Nomadic stock-breeding cultures; Eurasia; Early Metal Age; Archaeometallurgy; Radiocarbon chronology.

Palabras clave: Culturas ganaderas nómadas; Eurasia; Primera Edad del Metal; Arqueometalurgia; Cronología radiocarbónica.

\section{INTRODUCTORY NOTES: THE VIEW OF A HISTORIAN AND ARCHEOLOGIST}

Modern research shows that at their apogee the stockbreeding cultures of the Eurasian "steppe belt" covered a gigantic territory. From West to East, from the Middle Danube basin to Manchuria the distances exceeded 8000 kilometers without any noticeable breaks. In those times the territories occupied by mobile, aggressive steppe peoples was no less than 7 to 8 million $\mathrm{km}^{2}$ (Fig. 1) - and this during comparatively "peaceful" periods of their existence!

For a very long period of time the steppe zone was the basic "domain" of the stockbreeding cultures (1). However it seems equally clear that these groups also occupied forest steppe regions located to the North (as these were much more suitable biologically for cattle herders). Besides,

(1) Stockbreeding unconditionally and absolutely dominated the economy of this population. Farming -when it occurred among more settled populations- was always a rudimentary, subordinated activity and never played an important role in the lives of these peoples (Lebedeva 2005). 
all these populations wandered everywhere, not only in semi-deserts but also in more hostile desert regions from the Transcaspian Kara Kum and Kizyl Kum deserts to the Central Asian Gobi. Stock-keepers from the steppe communities could be encountered in the southern outskirts of mountainous taiga regions (e.g., in the SayanAltai). Thus, the notion of the steppe belt should be understood as a conditional one: in reality this belt included in its orbit a much more extensive area. It is in this sense that the term is used in this article.

One should also remember that the area under study was not cut off from the southern areas of settled farming and the northern (forest) worlds by strict boundaries. On the contrary, given the huge extent of the steppe belt, during all periods there were territories where steppe peoples overlapped and coexisted with very different types of cultures.

For example, at the western, Danubian end of their distribution (Ecsedy 1979; Jovanovic 1979) steppe stockbreeders intruded into the territory of indigenous settled agriculturalists from the Copper Age into the Middle Ages. Likewise, some researchers attach special importance to the so-called "Bactriana-Margiana Archeological Complex" (Kohl 2007: 182-213) in south-central Asia, where "civilized" farming populations and "barbarian" cattle herders from the steppe cooperated.

In historical reality the territorial scope of cultures of the steppe belt was always expanding and contracting. In case of success the dynamic warrior cattlemen could oppress alien populations over truly vast spaces. The aggressive aspirations of the steppe men were aimed, as a rule, southwards: they tried to intrude deeply into the zone of settled agricultural cultures. Weakening suddenly, they immediately rolled away to the north. By contrast, the forest cultures stayed at their back and most likely, to a greater or lesser degree, remained dependent on the steppe cultures.

Over the last six millennia, that is to say, from the Copper Age into the Modern Era, the steppe belt cultures undoubtedly were one of the most amazing phenomena in history of Eurasia. Alldestroying invasions by invincible steppe horsemen often plunged the will of the sedentary cultures into a literal paralysis.

The long historical memories of many peoples habitually referred to as "civilized" paint pictures of the past full of blood and the gloom of total destruction. Not only written sources, but also oral tales and epic legends are filled with such memories.

"Who are these fiends? From whence come these monsters? From what deserted depths? From the strange and God-accursed country of the Tartar? These devil creations are said to eat the flesh of the dead and speak an unknown language. The Lord could only have sent this infernal misfortune on our people for heavy sins". In the XIII century many rulers in Christian Europe were tormenting themselves with such ideas (Yurchenko 2002: 32-74). Similar laments were heard in many areas of Asia.

These were associated with the beginning of Ghengis Khan's conquests. The all-embracing Eurasian Empire of the Genghisids - the direct heirs of Genghis Khan - was both the apogee and the final act of steppe violence, its swan song. The sharply negative medieval estimations of the crushing Tatar-Mongolian conquests have dominated historical accounts. L.N. Gumilev is the only researcher known to the author to act as a vigorous and consequential apologist of these pernicious disasters that (as he believed) were not disasters at all and more likely even blessings (Gumilev 1989) (2).

The terrifying Mongol conquests were only the last of a long chain of similar disasters, however. The Huns led by the legendary Attila were worthy predecessors of Ghengis Khan. They appeared in western Eurasia from unknown frightening areas to the East. Unrestrained Hun horsemen struck crushing blows on both the eastern and western parts of the once-integrated Roman empire and, in the $\mathrm{V}$ century, reached the vicinity of modern Paris before their ruthless run was stopped.

(2) Gumilev (1989) glorified the Mongolian yoke in many of his works. He regarded it as such a good thing that it required no proof: first of all, the Mongols successfully defended Old Russia from external enemies. In Mongolia, of course, the cult of Genghis Khan is still preserved. Here it is necessary to note, however, that a completely black portrait of the cultures of steppe and desert nomads would do them little justice.

We should recollect that some ideas arose among mobile herders that played a special role in the history of mankind. Examples might include monotheism among the ancient Jews in the III and II millennia BC or Islam among the semi-nomadic and nomadic inhabitants of the Arabian peninsula. In addition, a number of technological innovations were developed by steppe herders, as archaeometallurgy demonstrates. 
In the I millennium BC the ScythianSarmatian culture occupied the steppes from the lower Danube to western Mongolia. The kurgan burials of Scythian-Sarmatian leaders with their grave goods rich in gold and other spectacular finds excite the interest of both research archeologists and the general public even now. The Scythians made incursions south of the main Caucasus range. At the end of VI century BC Darius and the Persian army tried to punish and break one small group of Scythian-Sarmatians, but all his attempts failed completely. Herodotus described the events in detail, and his narration makes clear the strategic invulnerability of the steppe.

China most likely suffered the most from the painful and at times tragic collisions with the world of the steppe cultures. And this struggle lasted not less than three millennia, until the late Middle Ages. One should take into account that in western Eurasia the southern world was separated from the northern one of the steppes by great mountain ranges (the Caucasus, the Pamirs, the Tien Shan), while the Chinese had to build the Great Wall, which proved to be a very weak barrier against flying groups of "steppe cowboys" (3).

The first signs of the frightening Eurasian steppe belt phenomenon appear at the beginning of the Copper Age, i.e. in the V millennium BC. $\mathrm{By}$ the end of the II millennium BC, the borders of the steppe belt had developed features that would characterize it for the next three millennia (Fig. 1).

The primary goal of this article is to distinguish the general stages of formation of steppe belt cultures during the Early Metal Age (4). At present, one can establish three such stages. In addition, it is possible to distinguish also a number of consecutive subphases within the second and the third stages. The base of the present research are extensive databases on the ancient metal objects and radiocarbon dates, stored and

(3) A. Morales and E. Antipina (2003) have used this expressive and vivid term to characterize the steppe warriors of the Bronze Age.

(4) The limited size of the present article dictates a lapidary presentation of the evidence in summarized diagrams of the distribution of the sums of probabilities of the calibrated radiocarbon dates and general geographical maps. It is also clear that here we can concentrate attention only on the key problems (Chernyj 1993a) and archeological communities, to the detriment of many others.

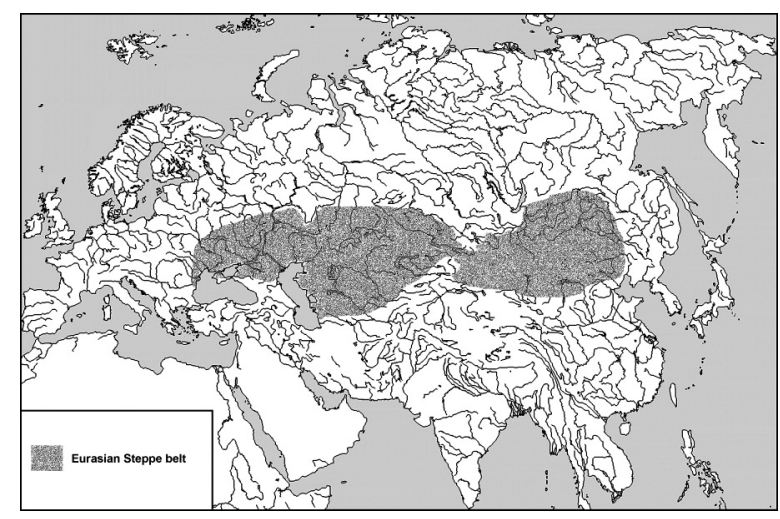

Fig. 1. Schematic map of the "Steppe belt domain" of Eurasian stock-breeding cultures.

systematized in the Laboratory of the Institute of Archeology of the Russian Academy of Sciences (Chernij 1993b). The databases on metal from various metallurgical provinces (MP) include more than 120000 objects. There are nearly 1700 calibrated ${ }^{14} \mathrm{C}$ dates.

\section{THE EARLY (FIRST) STAGE OF THE FORMATION OF STEPPE BELT CULTURES: THE CARPATHO-BALKAN METALLURGICAL PROVINCE}

The beginning of the "steppe belt" stockbreeding cultural formation is probably connected with the origin of the Carpatho-Balkan metallurgical province (CBMP) of the Copper Age and its swift explosive formation (Chernykh 1992: 35-53). In the period of maximal distribution and production of metal, the province's territory was about 1.3-1.4 million $\mathrm{km}^{2}$ (Fig. 2). Within the array of mining and metallurgical centers composing the structure of the province, three basic groups of cultures can be reliably distinguished.

The first and principal CBMP bloc consists of the mining and metallurgical centers localized in the northern Balkans and the Carpathian basin (Fig. 2A). Huge numbers of copper tools, weapons (Fig. 3A) and ornaments were produced in these centers (Todorova 1999). The cultures of this bloc include such unique sites as the Varna gold necropolis and the Ai Bunar copper mine, the most ancient mine in the world known to date 




Fig. 2. Schematic map of the Carpatho-Balkan metallurgical province area. $\boldsymbol{A}$ - Central bloc of settled farming cultures and communities. $\boldsymbol{A}-\mathbf{1}$-Butmir; $\boldsymbol{A}-\mathbf{2}$ - Vinca C/D; $\boldsymbol{A}-\mathbf{3}$ - Karanovo V-Maritsa; $\boldsymbol{A}-\mathbf{4}$ - Karanovo VI-Gumelniţa; $\boldsymbol{A}-5$ - Varna; $\boldsymbol{A}-\mathbf{6}$ - Lengyel; $\boldsymbol{A}$-7 - Tiszapolgar; $\boldsymbol{A}-\boldsymbol{8}$ - Bodrogkresztur. $\boldsymbol{B}$ - Cultural block Cucuteni - Tripol'ye. $\boldsymbol{C}-$ block of the steppe stock-breeding cultures. $\boldsymbol{C}-\mathbf{1}$ - Dnepro-Donets or Mariupol'; $\boldsymbol{C}$-2 -Sredni Stog; $\boldsymbol{C}-3$ - Khvalynsk.

that has been surveyed in detail. This bloc covers about $0.75-0.8$ million $\mathrm{km}^{2}$.

The second bloc consists of cultures of the Tripol'ye (or Cucuteni-Tripol'ye) group (0.16-0.18 million $\mathrm{km}^{2}$ ) and should be regarded as peripheral in relation to the northern Balkan/Carpathian CBMP bloc (Fig. 2B). This certainly seems to be the case with respect to metal production. Within the Tripol'ye cultural bloc it is reasonable to distinguish three subgroups: Tripol'ye A, B and C1. In the Tripol'ye community the centers of metal production were relatively small when compared to the northern Balkan/Carpathian CBMP bloc. Tripol'ye workmen produced weapons and ornaments using copper imported from main bloc of the CBMP. The Tripol'ye bloc became the main transshipment point of copper eastwards to the area occupied by the steppe populations (Černych 1991).

The third, easternmost (or northeasternmost) and definitely marginal bloc of the CBMP occupied a territory some $0.4-0.5$ million $\mathrm{km}^{2}$. It was composed entirely of cultures or, to be more exact, archaeological communities of steppe stockbreeders. The schematic map (Fig. 2C) presents the distribution of these communities. However their "pinpoint" presence in the Danube zone of settled farming cultures is also quite obvious (see, for example: Comşa 1991).
The steppe communities of southeastern Europe exhibit some substantial peculiarities. Archaeologists who conduct research into the domestic and mortuary sites of the steppe bloc separate them not only from rather distant settlements and necropolises, such as those on the Danube, but also from adjoining Tripol'ye settlements. Here distinctions are obvious in the whole complex of the basic attributes of cultures; but this is true only for external comparisons of this bloc of cultures. When these researchers try to identify obvious and reliable distinctions in the internal structures of these communities, at times they arrive at mutually exclusive conclusions, however. Written and spoken discussions of these problems - which in this case are probably ineradicable - at times become severe. All attempts to identify correctly separate cultures rest on a washed, "blurred" picture of the distinct features of each, and certain key points remain buried in the huge mass of the currently collected archeological materials. When studying steppe cultures, we constantly come across striking manifestations of the so-called "syndrome of cultural continuity" so characteristic for the majority of cultures of the steppe belt of Eurasia (Chernykh 2007: 35-36) (5).

(5) However this "syndrome" is to no small degree inher- 
Within the eastern sector of the CBMP it seems to the author that one should concentrate mainly on three archeological communities: Dnieper-Donets, Sredni Stog, and Khvalynsk cultures (Figs. 2 and 3). In the literature these appear under an amazing variety of names. Thus, certain groups of burial grounds or settlements of the Dnieper-Donets community can be called "neo-neolithic sites", or sites of the "Novo-Danilovka type" sites, or culture of the "Mariupol' necropolis type", etc. (6).

In this respect the fullest, and most curious, report on the materials from necropolises of the fifth to fourth millennia BC on the Northern Black Sea Coast is that of J.J. Rassamakin (2004). Compared to the metallurgical and metal processing production of the two western blocs of the CBMP, metal working in the third, peripheral bloc was rather primitive (Ryndina 1998: 151-179). In essence, it did not meet the general morphological technological standards of the CBMP: they did not manufacture - or were not able to manufacture - the magnificent metal weapons for which the centers of the central zone are so famous (Fig. 3B). The only basis for inclusion of the steppe centers of metal processing in the CBMP is the copper that the peoples of the steppes imported from western areas.

Absolute dates for the cultures and communities of all three blocs were established on the basis of 470 calibrated radiocarbon dates (supported by calculation of the sum of probabilities for each cultural group) (Fig. 4). In reality the total number of known dates is now much larger, most of the recent ones deriving from sites of the main bloc of the Carpatho-Balkan cultures. For the purposes of the present work, however, the corpus of dates we have included is sufficient. Almost half of the dates (230 in all) come from the central bloc of the CBMP. These show that the

ent, for example, to the cultures of the East European and Western Siberian forest zones.

(6) The debates reflecting disagreements of a similar sort can be found in a variety of books and articles (see, for example Arkheologiia 1985: 204-205, 305-320; Telegin 1991; Telegin et al. 2000; Kotova 2002: 5-11; and other works). In this respect the fullest, and most curious, report on the materials from necropolises of the fifth to fourth millennia BC on the Northern Black Sea Coast is that of J.J. Rassamakin (2004). On the basis of analysis of almost one thousand burials the author identified four groups of burial places (or funeral traditions). However, in the opinion of the author of the present article, the four funeral traditions suggested by J.J. Rassamakin perfectly confirm the undeniable nature of the "syndrome of cultural continuity" which is so characteristic of the bloc of steppe communities.



Fig. 3. Carpatho-Balkan metallurgical province: copper heavy tools/weapons and ornaments. $\boldsymbol{A}$ - Central bloc of settled farming cultures and communities; $\boldsymbol{B}-$ bloc of the steppe stock-breeding cultures.

apogee of metallurgical activity in the central bloc of the CBMP covers a five-century time interval - between the 4700 and the 4200 BC. By contrast, the known dates for sites of the other blocs are much fewer: 139 dates for the three basic cultures of the Tripol'ye complex and 101 dates for the steppe communities.

In this case we must draw attention to the character of distribution of the sums of probabilities of the calibrated radiocarbon dates in all three blocs: the diagrams slightly reveal a rather diverse picture. In the central bloc most frequency ranges of the sums of probabilities are compact and approximate normal distribution (Fig. 4). By contrast, the sums of probabilities for dates for the three Tripol'ye complexes are much less compact: their $68 \%$ probability ranges cover the better part of their total distribution.

Second, the dates for the basic stages (cultures) of the Tripol'ye community (A, B and C1) obviously cover quite distinct ranges. Besides, it is rather curious that Tripol'ye A sites basically predate metal and in essence are still in the Neolithic period.

The Tripol'ye B period coincides with apogee of CBMP metallurgical activity, though mainly with its later centuries. The culture of the 


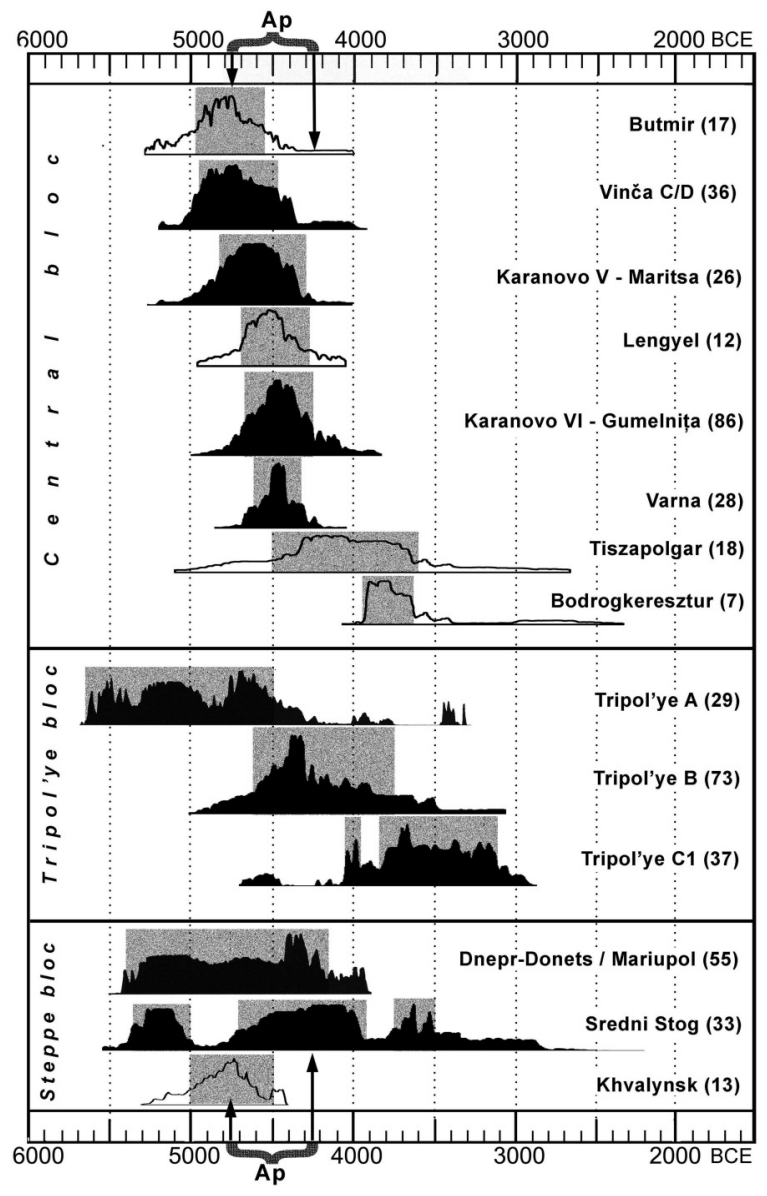

Fig. 4. Summed probabilities of radiocarbon dates of archaeological cultures and communities of the Carpatho-Balkan metallurgical province. Note: the rectangle darkening for every polygon corresponds to a probability dispersion of $68.2 \%$ (it is conformed to the figures 3, 5, 6, 10). $\boldsymbol{A p}$ - the apogee of activity of the central bloc's productive centers of the Carpatho-Balkan metallurgical province.

Tripol'ye $\mathrm{C} 1$ period entirely post dates that apogee and corresponds to the dissolution of this most ancient Eurasian metallurgical province. (We shall return to the question of the synchronization of Tripol'ye C1 with the beginning of the functioning of the Circumpontic province in the following section of the article.)

The summed probabilities of the calibrated dates of the steppe culture bloc differ significantly from those just discussed. Here the dominant character of distribution is chaotic, particularly with respect to the Sredni Stog culture. The distribution of dates for the Khvalynsk culture is more compact, but here we have only 13 reliable dates all belonging to the two easternmost burial grounds of the steppe bloc (Fig. 4).

\section{THE SECOND STAGE OF FORMATION OF THE STEPPE BELT: THE CIRCUMPONTIC METALLURGICAL PROVINCE}

At the end of the $\mathrm{V}$ and the beginning of the IV millennium $\mathrm{BC}$ there was a dramatic change in the cultural-economic systems of the Copper Age.

The central event of this epoch was the disintegration of the Carpatho-Balkan metallurgical province and the parallel formation of a new and huge Circumpontic metallurgical province [CMP], marking the beginning of the epoch of the Early Bronze Age. At the final stage of its existence the CMP covered 4.5-5 million $\mathrm{km}^{2}$. The system of CMP mining, metallurgical, and metal processing centers stretched from the Adriatic Sea to the southern Urals west to east and from the Levant, Mesopotamia and Susiana up to the forest areas of the Upper Volga region south to north.

The accumulation, ordering and statistical processing of a large series of radiocarbon dates have required the author to change his former understanding of the character and development of this province (Chernij et al. 1990), the key for understanding the metallurgy of all Eurasia. We present here the results of the systematic processing of 833 calibrated radiocarbon dates from numerous suites of communities, cultures and individual sites (7). As a result of this work the formation and functioning of the huge CMP system can be divided into two major chronological phases. The author's current understanding of the nature and significance of each these chronological steps are notably different from his earlier interpretations.

The first phase covers the initial formation of the province, and the author prefers to call it the "proto-CMP". This represents a return to the terminology formulated in the first large work applying radiocarbon chronology to the metalproducing centers of the Carpatho-Balkan and

(7) These 883 dates represent only the most necessary dates selected for the present article. In reality the number of radiocarbon dates for the whole CMP system is much larger. 
Circumpontic provinces (Chernykh et al. 2000: 14-18, 37-38).

In fact the chronological range of this early phase includes the whole IV millennium BC. The prefix "proto" indicates that the territory of the productive centers of the CMP initially did not include all subsequent "Circumpontic" areas (Fig. 5). The northern Balkan peninsula, the Carpathian and Danube basins and the steppe zone of the northern Black Sea Coast remained within the borders of the dying Carpatho-Balkan province.

In the second phase a true Circumpontic province develops: its productive centers completely encircle the basin of the Black Sea. By then the disintegration of the CBMP is completed and its former territories are occupied by metallurgical and metal processing centers in which the morphological and technological standards of the CMP are completely dominant. This second phase covers the entire III millennium BC.

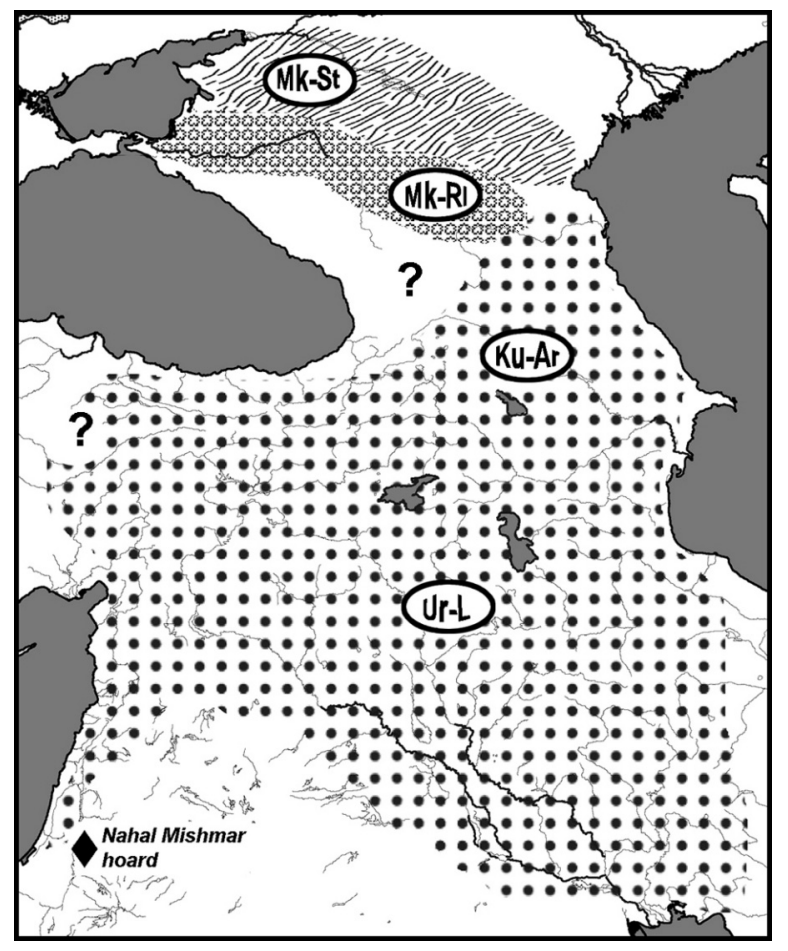

Fig. 5. Schematic map of the Circumpontic metallurgical province (early phase of the province formation). $\boldsymbol{M} \boldsymbol{k}-\boldsymbol{R} \boldsymbol{l}-$ Maikop culture/community; $\boldsymbol{M} \boldsymbol{k}$-St - s.c. "Steppe Maikop"; $\boldsymbol{K} \boldsymbol{u}$ - $\boldsymbol{A} \boldsymbol{r}-\mathrm{Kura}-$ Arax culture; $\boldsymbol{U} \boldsymbol{r}-\boldsymbol{L}$ - Late Northern Uruk.
During both phases of its existence the gigantic CMP is characterized by a number of rather remarkable features. The first and probably most essential of them is the new technological and morphological standards of metal-working, ones very different from the main attributes of the disintegrating CBMP system. This involves not only the categories and forms of the tools and weapons, but also the first widescale use of artificial copper-arsenic alloys (arsenical bronzes). These new methods of smelting and processing of metal developed in the CMP centers formed the basis of the first global metallurgical system, the so-called West-Eurasian model of metallurgical production. Later - by the beginning of the II millennium $\mathrm{BC}$ - the differences between the West-Eurasian and East-Asian models become rather clear.

Another important feature of the CMP that is present from its earliest stages is its division into two contrasting bloc of archeological cultures: a southern bloc consisting of settled farming cultures and communities and a northern bloc represented by the so-called kurgan cultures of the steppe.

Finally, the third feature one should mention is that within this vast array of diverse cultures the steppe world began to play an extremely important role, one absolutely different from what we observed for it during the CBMP Copper Age. The distinctly marginal character of the steppe stockbreeding cultures of the Copper Age with respect not only to the central bloc of the CBMP cultures, but also to the block of Tripol'ye communities fell into oblivion.

\section{The first CMP phase: the Maikop phenomenon}

The famous Maikop culture must be put at the foreground of the CMP formation. In a number of respects the Maikop phenomenon is both extraordinary and paradoxical. The metal from its kurgan burials have defined the culture for nearly a century and undoubtedly is its most important attribute (Munchaev 1975: 211-335; 1994: 104-119; Rezepkin 2000). Nowhere in the southern sector of the early CMP, in any of the numerous Early Bronze Age (EBA) cultures and sites of the Near East, do we find anything equal to the bronze, gold and silver productions of the Maikop "royal" complexes either qualitatively or 
quantitatively (Fig. 6) (Chernykh et al. 2002: 5-15, Fig. 3). Any interpretation of the magnificent Maikop metal complexes as some kind of local response to decisive Near-Eastern influences faces an insurmountable barrier, namely the absence in the southern zone of the province of anything that surpasses or even equals Maikop metal.

The Maikop kurgans were built by the emergent stockbreeding cultures of the northern zone of the Circumpontic province. Due to its complexity and large scale the Maikop culture is undoubtedly the most impressive of all the steppe kurgan communities of eastern Europe. What is more, of all the many kurgan cultures, the Maikop community occupied a rather peculiar boundary area as if "resting" on the foothills of the Great Caucasus. Other CMP communities located across the mountainous peaks of the Caucasus were very different from the kurgan cultures (Fig. 5). The Maikop culture also differed from other, more northerly kurgan communities of greater antiquity.

Further analysis of the Maikop phenomenon leads us into its paradoxical aspects. Thus, it is absolutely impossible to overlook the sharp contrast between the magnificence of the kurgan

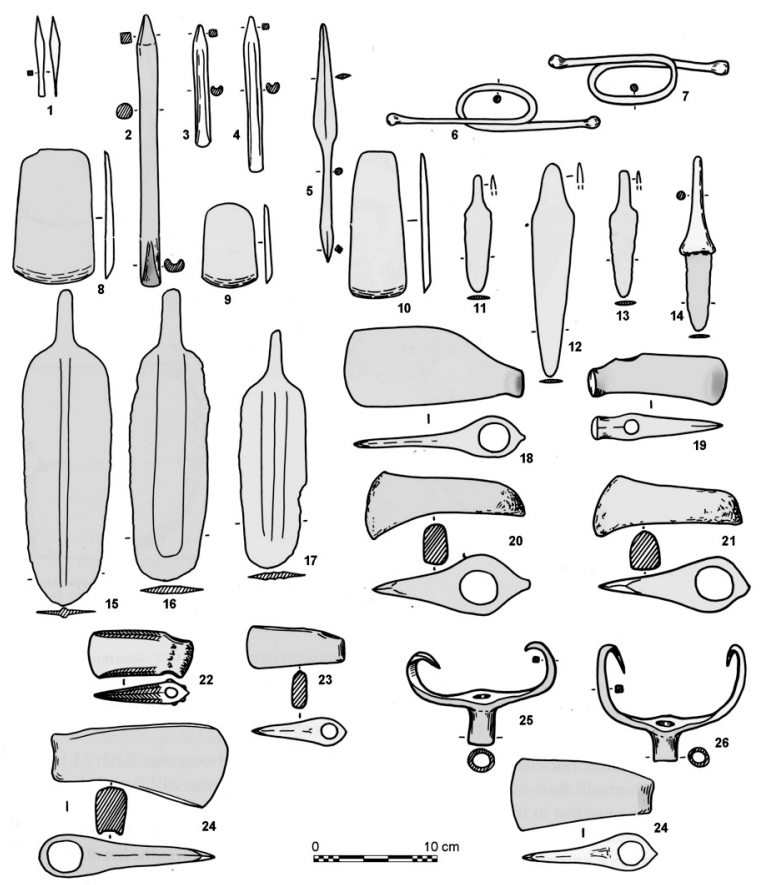

Fig. 6. Circumpontic metallurgical province, early phase: arsenical bronzes of the Maikop culture/community. burial places and the rather modest (indeed, at times, poor) character of the settlements connected with them. Even the most remarkable Maikop settlement - Meshoko, south of the Kuban river with its stone defensive wall (Formozov 1965: 70-105) - can hardly be put in the same hierarchical range as the famous kurgans. Other settlements of this culture are much less expressive.

One more paradox: antiquities of this type have been studied for more than a century, and Maikop funerary and domestic assemblages have provided not a single sign of the fact that the carriers of this culture were occupied with mining, metallurgical production, metallurgy, or even metal processing. This contrast is especially striking, given the amount, diversity and quality of the metal finds recovered from kurgan cemeteries.

Here we must draw attention to a surprising feature of Maikop antiquities. Radiocarbon dates indicate that the chronological range of Maikop sites is more ancient than had been assumed earlier based on comparisons of the categories and types of archaeological materials. The $68 \%$ confidence range for the 37 dates from Maikop contexts indicates a chronological range of 4050-3050 BC (Fig. 7). Equally extremely important is fact that 19 dates for "steppe Maikop" (8) sites fall within practically the same time range, namely 4000-3000 BC (Fig. 7).

Furthermore, it is amazing that the calendar age of the Maikop cultures appears to be more ancient than many other communities, cultures, and settlements (tells) of the Early Bronze Age in the southern bloc of the CMP (Fig. 7). Only sites of the so-called late "northern Uruk" (i.e., well-known Uruk northern expansion) are synchronous with the Maikop complexes. And we should remember that sites of the Uruk type are extremely poor in metal. That sites of the Kura-Araxes culture are younger than Maikop (Fig. 7) is also surprising. The paradox resides in the fact that the Maikop culture was always considered as a secondary one with respect to Uruk and Kura-Araxes, at least with respect to metallurgy and metal processing. The problem briefly

(8) By "steppe Maikop" we mean kurgan funerary complexes located in the steppe zone north of the Kuban and Terek basins, between the Sea of Azov and the Caspian Seas, i.e., outside the area occupied by the "native" Maikop culture (Fig. 4). The inventory of these complexes contains items (mainly pottery) of Maikop appearance. 


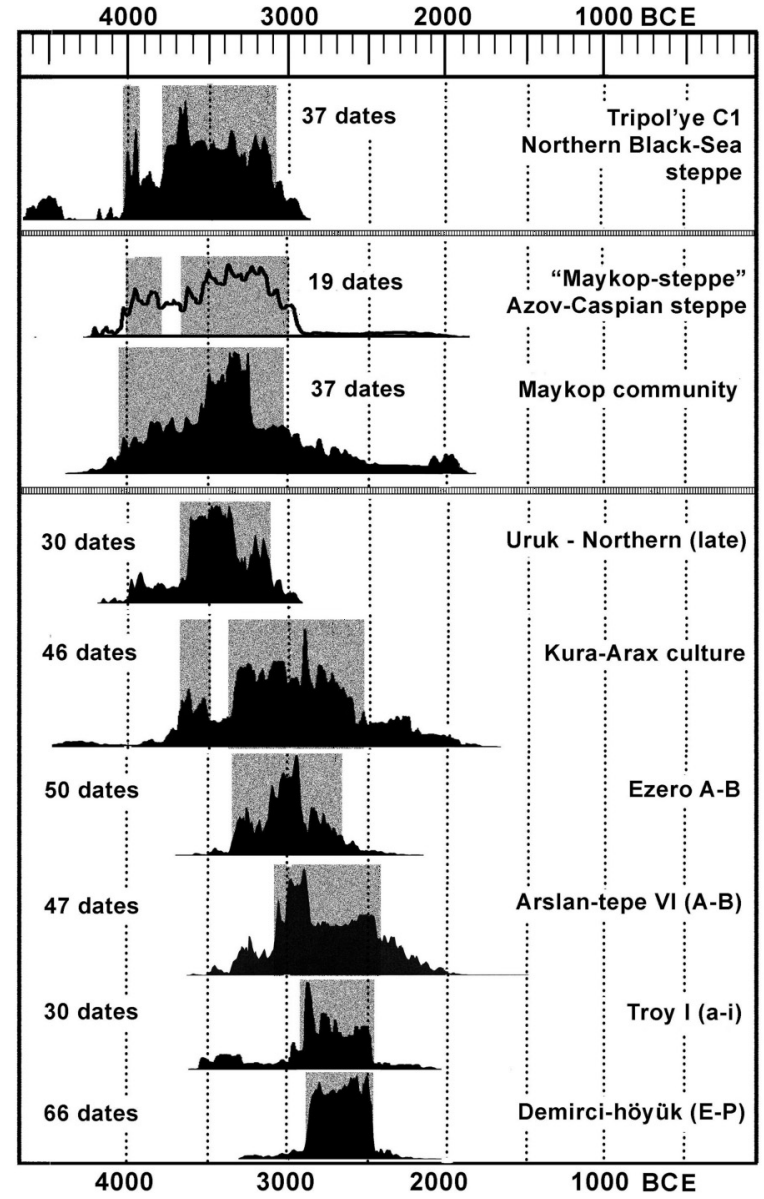

Fig. 7. Summed probabilities of radiocarbon dates of archaeological cultures and communities of the Circumpontic metallurgical province (the Tripol'ye $\mathrm{C} 1$ culture is part of the Carpatho-Balkan metallurgical province; see fig. 3).

formulated here undoubtedly will demand much more detailed study (9).

The Maikop culture is also earlier than the bloc of steppe cultures and communities in eastern Europe. This once again emphasizes the unusual character of the large Maikop kurgans, where the graves were really rich in various metals - gold, silver, bronze.

(9) In the southern zone of the CMP it is nearly impossible to find assemblages of metal objects comparable to those of the Maikop culture. The Nahal Mishmar hoard from Palestine (Fig. 4) is one widely known exception, sharply abnormal in terms not just of its metal but also of its dates (Bar-Adon 1980): the 13 radiocarbon dates known to the author, all upon various organics accompanying the hoard, range from 5000 up to 3500 years $\mathrm{BC}-$ and this at $68 \%$ of probability! For a hoard this is very impressive and hard to explain.
To conclude this section, we should pay special attention to the synchronism between the time ranges for Maikop (of the florescent Circumpontic province, and Tripol'ye C1 (Fig. 7), of the dying Carpatho-Balkan province. The Maikop culture and Tripol'ye C1 were situated in different territories and there were no obvious contacts between them.

\section{The later second CMP phase: the steppe kurgan cultures}

Within the centers of metallurgy and metal processing of the kurgan cultures bloc, researchers usually distinguish two major archeological communities: the Yamnaya (Pit-grave) and Catacomb communities. Yamnaya is known to us essentially only from materials in kurgan burials (settlements here are exceedingly rare). Considerable numbers of copper and arsenical bronzes were found in the cemeteries of the steppe communities (Fig. 8). In the Catacomb community settlements are more frequent, but funerary as-

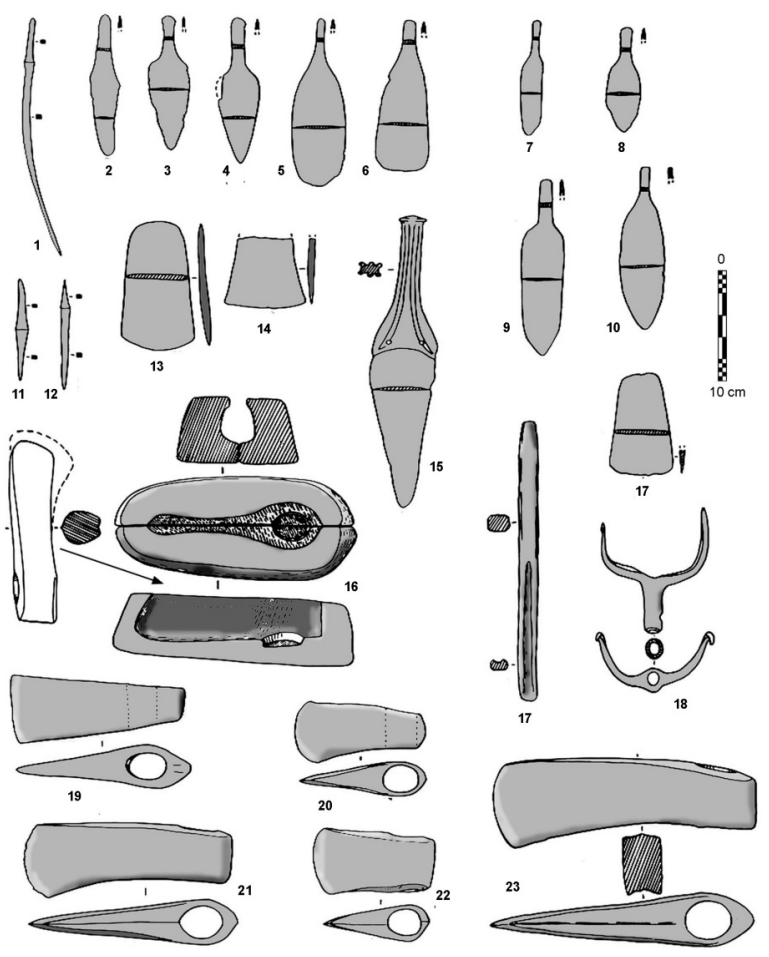

Fig. 8. Circumpontic metallurgical province - second phase: copper and arsenical bronze tools and weapons of the steppe kurgan stock-breeding cultures. 
semblages from kurgans dominate the available information. The majority of researchers traditionally have thought (and even now still think) that in the steppe and forest-steppe zones of eastern Europe the Middle Bronze Age Catacomb community replaces the Early Bronze Age Yamnaya community. Recently, however, much more attention is paid to the substantial evidence that these complexes co-existed during a long period of time. The radiocarbon chronology strengthens the position of the adherents of partial Yamnaya-Catacomb contemporaneity.

Comparative analysis of the sums of probabilities of radiocarbon dates from both complexes shows that the dating differences between them are not very significant. This conclusion is based on a rather representative series of radiocarbon dates: 273 dates for Yamnaya complexes and 191 for the Catacomb groups. Comparison of their distributions leads to the conclusion that their $68 \%$ confidence ranges overlap between 2700 and 2100 BC (Fig. 9).

The formation of the Yamnaya community occurs at the end of the IV millennium or in the first centuries of the III millennium BC. Thus it is rather curious that the earliest dates (3300 to $3000 \mathrm{BC}$ ) are from sites of the two geographically peripheral regions of the community, both eastern and western. We mean the Volga-Ural area (including also sites of the Poltavka type) and the northwest Black Sea coast (Fig. 9). In the central regions of the community - the basins of Dnieper, southern Bug, Don and Donets, and also Kalmykia - the early end of the $68 \%$ probability range for the summed radiocarbon distributions is about $2650 \mathrm{BC}$, three or four centuries later than the previously mentioned peripheral complexes.

For the three main subgroups of the Catacomb community the picture is a little bit different. Here a rather small chronological priority is accorded to the geographically central complexes, which are localized in the basin of the Don and Severski Donets (Fig. 9), while those of the peripheral regions - Kalmykia and particularly the basins of the Dnieper and southern Bug - are later.

On the whole the early end of the calendar range for the Catacomb community is two to three centuries later than the comparable moment for the Yamnaya cultures. Likewise, the end of the Catacomb complex also occurs two to three

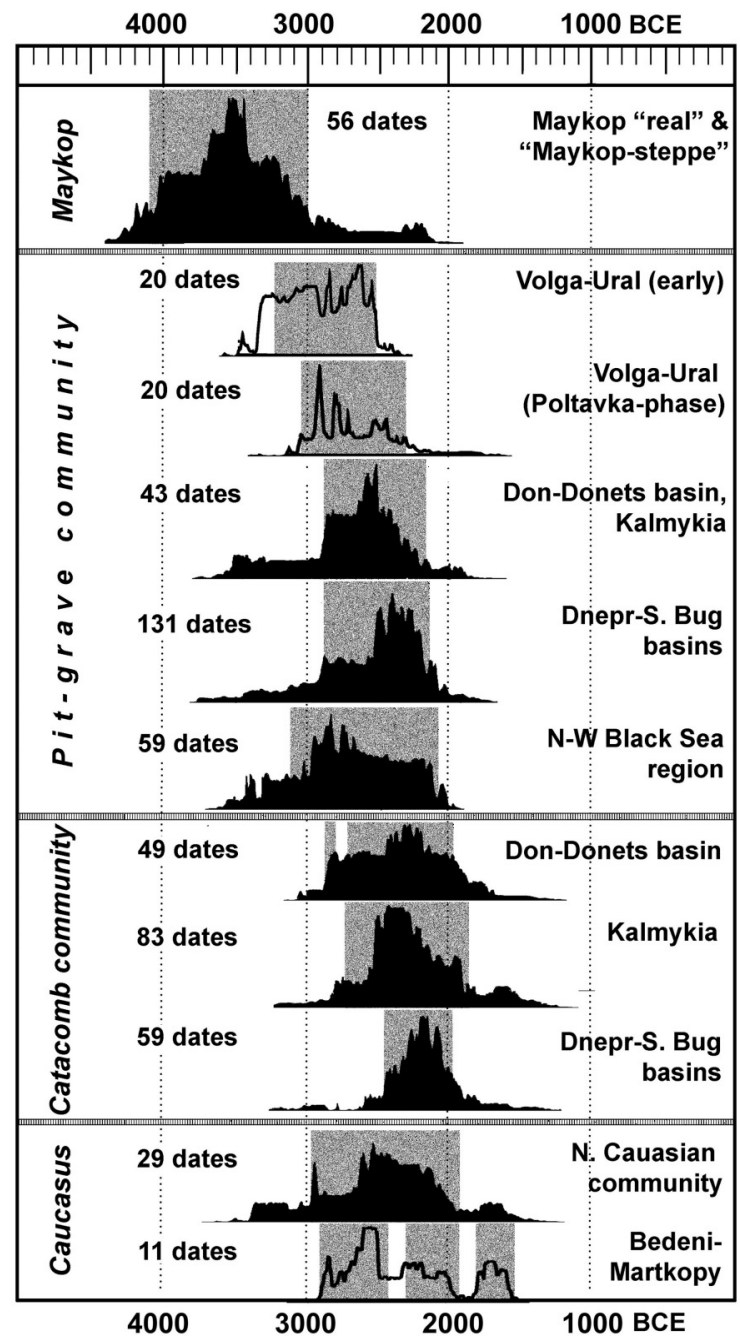

Fig. 9. Summed probabilities of radiocarbon dates of the stock-breeding archaeological cultures and communities of the Circumpontic metallurgical province (mainly northern bloc of the CMP).

centuries later: the $68 \%$ probability range indicates this would have occurred around 2000 to $1800 \mathrm{BC}$.

We have to admit that the radiocarbon chronology contradicts our earlier ideas about the calendar position of the main Eastern European steppe communities. In addition, the radiocarbon dates correct the relation of the steppe cultures with those of the northern Caucasian archeological community, including the kurgan cultures of the Bedeni-Martkopi type that succeeds the Maikop culture (Dzhaparidze 1998). Diagrams of distribution of the sums of their probabilities shows that these complexes were contemporane- 


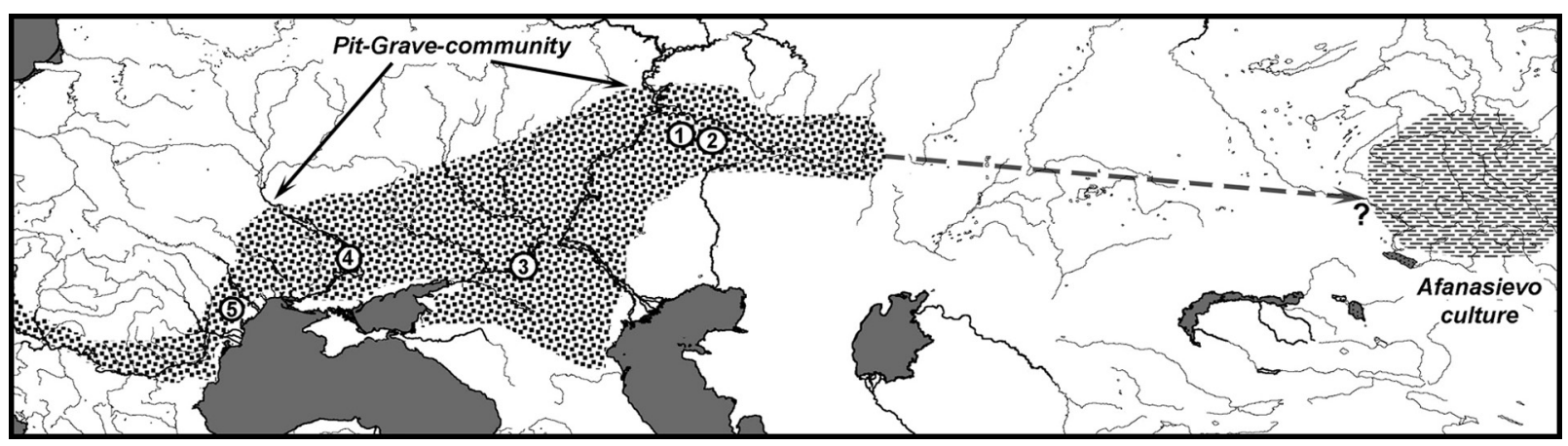

Fig. 10. Schematic map of the Pit-grave (Yamnaya) archaeological community (second phase of the CMP) and its proposed relation with Altay region (Afanasievo culture). Distribution of variants of the Pit-grave community: 1 - Volga-Ural (in essence - Yamnaya culture); 2 - Volga-Ural (Poltavka culture); 3 - Kalmykia and Don-Donets basin; 4 - Dniepr and South Bug basins; 5 - N-W Black Sea area.

ous with the Yamnaya and Catacomb communities to the north.

\section{The Yamnaya and Catacomb communities: the problem of chronological correlations}

So, in a rather extensive territory of southeastern Europe, an area of no less than 0.7 million $\mathrm{km}^{2}$ (compare Figs. 10 and 11), two huge archaeological communities - Yamnaya and Catacomb - coexisted approximately during six hundred years. Originally - beginning with V.A. Gorodtsov's classical works (Gorodtsov 1905, 1907, 1916) - the Catacomb cultures were supposed to be later than Yamnaya because of the stratigraphy in some Catacomb graves. Subsequent researches also used the level of development of metal processing as nearly the main attribute permitting one to postulate this chronological succession: Catacomb metallurgy seemed more developed and perfect (Chernykh 1992: 83-91, 124-132). Similar arguments were used to suggest comparatively late dates for sites of the Poltavka type, widespread in the Volga-Ural region (Chernykh 1992: 132-133).

The accumulation and systematic analysis of radiocarbon dates contradict our former ideas not only about the range of absolute calendar dates for these cultures, but also about their relative chronological position. Even more importantly, however, this systematization of an absolute calendar chronology for a variety of cultures casts into doubt what seemed to be an unshakeable axiom of archeological science. It was considered indisputable that things that were more perfect in form and technology necessarily should be later in time. The data we now have indicates that this cannot be considered as an unconditional axiom. More perfect ways of metal processing and technology can coexist not only with comparatively more backward ones, but even with primitive ones. Many confirmations of this can be found in the histories of Eurasian peoples (10).

Here we wish to emphasize, first, one essential difference between the Yamnaya and Catacomb communities with respect to their geographical distribution, influence and interrelations (Figs. 10 and 11). These maps make it clear that the geographic scope of sites of the related Yamnaya cultures is much greater than of Catacomb sites. Yamnaya's latitudinal extent is from Pannonia to the southern trans-Urals, no less than $3000 \mathrm{~km}$ (Fig. 10). The Catacomb community was settled in a much more compact territory from the Dniester to the middle and the lower Volga region. From West to East its extent did not exceed 1200 to $1400 \mathrm{~km}$ (Fig. 11).

And, secondly, in this connection it seems absolutely necessary to draw attention to one very important feature of the Yamnaya community. Its spatial influence reached amazingly far to the East - as far as the Altai (Fig. 10). There, in the Sayan-Altai mountain area the Afanasievo culture developed metal-working that was to influence the metal production of the Late Bronze cultures of the steppe belt and of eastern Eurasia as a whole.

The Yamnaya community also is different from the Catacomb one because it exploited its

(10) This issue is touched upon here very briefly and cannot be expanded upon within the limits of this article. It certainly demands more substantiation and systematic research. 




Fig. 11. Schematic map of the Catacomb archaeological community and others cultures (late phase of the CMP). Catacomb community: $\mathbf{1}$ - Don/Donets basin; 2 - Kalmykia; 3 - Dniepr and South Bug basins. N-Ca - NorthCaucasian archaeological community. Be-Ma - BedeniMartkopi kurgan culture.

"own" copper ore sources. Archaeological research on the famous Kargaly ore field situated in the southern Ural steppe periphery of this community has produced graphic evidence of mining and metallurgical production connected with the Yamnaya and Poltavka cultures of the northeastern CMP (Chernykh 2002: 128-139; 2005: 29-35; 2007a: 57-70; Díaz-del-Río et al. 2006).

By contrast, the Catacomb cultures were much more closely connected to the northern Black Sea area and especially to Caucasian metallurgy. Since the radiocarbon chronology leads us to the conclusion that the decline of the Catacomb community occurred two to three centuries after Yamnaya's decline, we can draw a very important conclusion: the end of the Circumpontic province was marked by a retraction of its eastern border westward to the Volga river (Fig. 11).

\section{THE THIRD STAGE OF THE STEPPE BELT FORMATION: THE EURASIAN AND THE EASTERN ASIAN METALLURGICAL PROVINCES}

The third stage of the steppe belt formation coincided with the advent of the Late Bronze Age (LBA). This period was a key one in the history of many Eurasian peoples: it was then that the structure of the Eurasian world was formed, its essential features remaining basically the same until the Christian Era or the epoch of the great geographical discoveries. The metallurgical cultures of Eurasia and the southern shores of the Mediterranean sea covered a territory of 40 to 43 million $\mathrm{km}^{2}$. The territorial domain of the archeological cultures of the steppe belt reached its maximal value of about 7-8 million $\mathrm{km}^{2}$, as was mentioned in the beginning of the article (Fig. 1).

One of the most important events of this critical period was the disintegration of the Circumpontic province and the origin of new formations of a similar sort on its "ruins". Basically the CMP was a kind of "primogenitor" of the West Eurasian model of mining and metallurgy. The LBA was also marked by the origin of another model of such production - the East Eurasian one.

After the disintegration of the CMP its northeastern (eastern European) zone served as the base for the formations of the huge Eurasian Metallurgical Province (EurAsMP). This bloc of related production centers extended from eastern Europe to the steppe and forest zones of Northwest Asia, as well as most of Central Asia up to the deserts of the Kara Kum, the foothills of the Pamir and Tien Shan mountains and even the Xinjang region (Chernykh 2007b: 37-109). Its maximum territorial scope reached 7.5 to 8 million $\mathrm{km}$. The Eurasian MP lasted approximately a thousand years - from the last centuries of the III to the end of the II millennium BC. In comparison with other provinces, the industrial centers of the Eurasian province probably preserved the basic morphological and technological standards of the broken CMP to the greatest extent (although these standards underwent essential modifications during the province's development).

With the development of EurAsMP, on the one hand, and what we prefer to call the East Asian metallurgical province (EasAsMP), on the other, the final territorial contours of the "steppe belt" cultures come into being. The EasAsMP is sharply different from the former, but regrettably in many important aspects it is much more poorly known.

Within the steppe domain (and the Eurasian MP), the Bronze Age brought important changes in the subsistence strategies and the management styles of the cattle herders. By about 2000 BC a settled style of dwelling began to supersede the nomadic and semi-nomadic way of life, although 
as specialized archaeozoological investigations show, stockbreeding still remained mobile in character (Antipina and Morales 2005: 41-42). Anyway, archeologists have identified traces of many thousands of large and small settlements left by populations of the stockbreeders in these most extensive spaces during this period. Farming remained outside the frameworks of interests of the inhabitants of these settlements. Necropolises are also frequent in the steppe, but kurgan burial places gradually start to give way to cemeteries without the construction of raised barrows.

By the end of the II millennium BC for the characteristic and earlier form of subsistence activity prevailed: the nomadic and semi-nomadic way of life that had characterized earlier stockbreeding cultures once again became stronger.

The Scythian-Sarmatian world that completely replaced the Late Bronze Age communities at the beginning of the I millennium BC also renewed the tradition (which had been absolutely forgotten in the LBA) of necropolises with huge "royal" kurgans laden with precious grave goods.

With the approach of the Late Bronze Age and the parallel formation of the EurAsMP province, a huge number of copper and also tin mines were discovered and began to be exploited. These are scattered mostly in the Asian part of the province (from the eastern Ural Mountains, through Kazakhstan, and up to the Rudny or western Altai).

Widescale production of tin bronzes also began. At this time the population of the Eurasian province zone completely met its own needs for metal. The ties to the centers of the Caucasian metallurgy, which had played so significant, even determinative, role when the standards of the CMP had dominated, now cease.

\section{The Eurasian metallurgical province - early phase: the counter "waves" of cultures}

We can distinguish three clear phases in the history of the province. In the first phase - the province's formative phase - the most important phenomena are two extremely swift countercurrents of populations moving across the spaces of northern Eurasia. Each was characterized by highly characteristic but at the same time amazingly different expressions of their respective cultural essences.
The first of these waves rolled from West to East. During its rapid movement a large archeological community, which we call the AbashevoSintashta community, was formed. This community was based on the materials of two widely known archeological cultures - Abashevo and Sintashta. The Petrovka culture - the easternmost in this whole chain of related sites - should most likely be attached to this community as well. The area of distribution of these three cultures finally exceeded one million $\mathrm{km}^{2}$. It stretched like a long tongue from the Upper Don basin and the forest Volga region to the steppes and forest-steppes of western Siberia (Fig. 12).

When we analyze the cultures of this community, the "syndrome of cultural continuity" mentioned above becomes clearly apparent. For example, it is hardly possible to draw a borderline between materials of the Abashevo culture, on the one hand, and those of Sintashta, on the other. The researchers meet similar difficulties attempting to differentiate between the Sintashta and the Petrovka cultures. The metal of these cultures is a modification the most important categories in the inventory of the disintegrated Circumpontic province.

The second wave moved from East to West and is associated with what may be one of the most amazing phenomena in the most ancient history of the Eurasian peoples. This transcultural phenomenon is widely known in the literature by the name of Seima-Turbino after two well-known burials - Seima and Turbino (Chernykh and Kuz'minykh 1989; Chernykh 1992: 215-234). This phenomenon was rooted in a group of somewhat diverse cultures of the steppe, mountain and even taiga zones of the Sayan-Altay mountain region and also of other regions adjoining SayanAltai to the South and West. The unique character of the antiquities of Seima-Turbino becomes obvious as one analyzes some of their key aspects.

First, extremely developed forms of metal weapons explode suddenly and unexpectedly across the historical arena. Bronze Seima-Turbino weapons and casting technology differ absolutely from what we come across in the West, within the limits of the CMP, and in particular from what the Abashevo-Sintashta community brought to the East (compare Figs. 13A and 14).

Second, Seima-Turbino antiquities are associated with absolutely dissimilar types of sites, especially when compared to Abashevo-Sintashta 


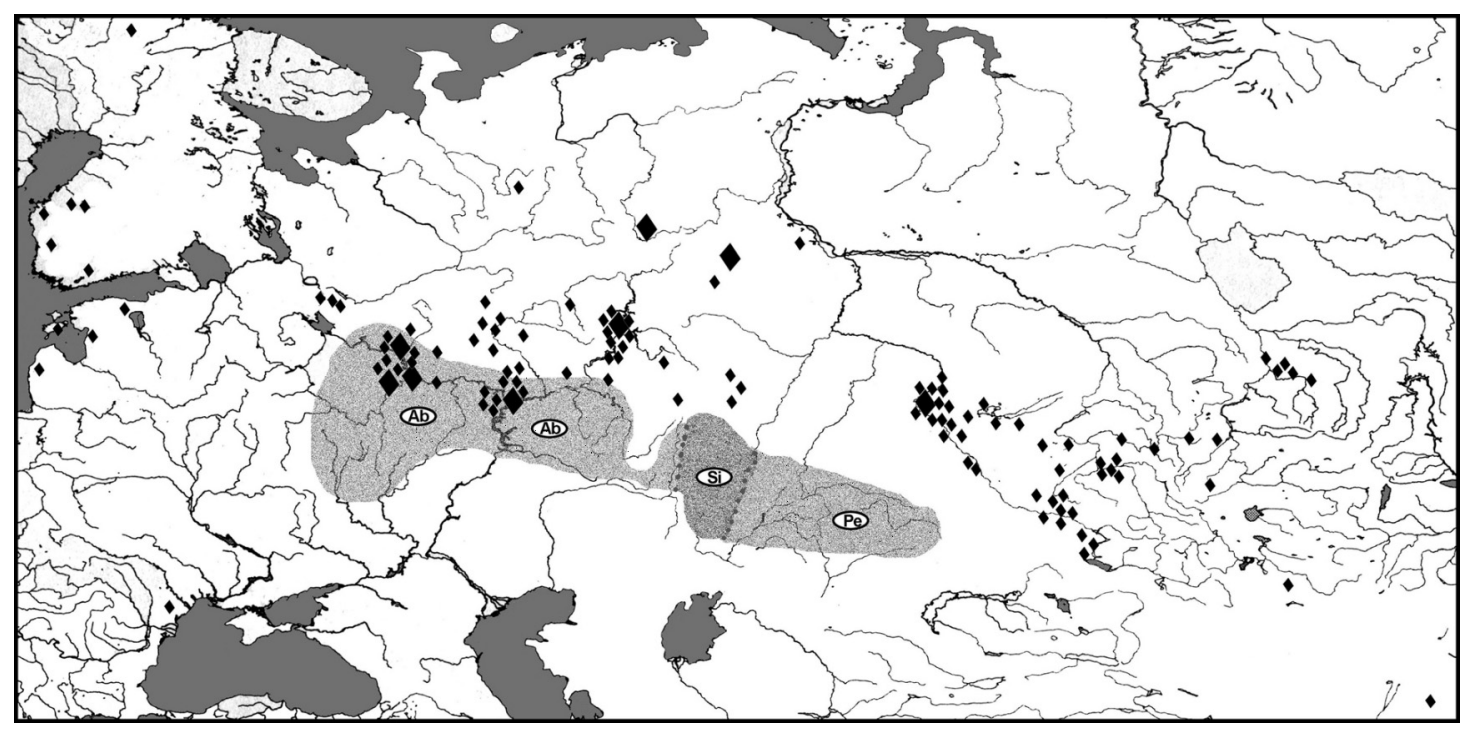

Fig. 12. Schematic map of the areas of the Seima-Turbino sites and metal (rhombic signs) and Abashevo-Sintashta archaeological community (the early or formation phase of the Eurasian metallurgical province). $\boldsymbol{A} \boldsymbol{b}-\mathrm{Abashevo}$ culture; $\boldsymbol{S i}$ - Sintashta culture; $\boldsymbol{P e}$ - Petrovka culture.

and the Petrovka settlements and necropolises. Seima-Turbino settlements are not known at all; archaeologists mainly deal with non-kurgan burials. In necropolises cenotaphs dominate: graves are outlined only by sets of metal products and also by stone and flint artifacts. Remains of human burials in the Seima-Turbino cemeteries are rather rare, as are ceramics. A rather large proportion of the metal finds known to us involve individual accidental finds, probably from destroyed tombs.

Third, it is not difficult to reconstruct the lightning swift movement of the military SeimaTurbino groups westwards from the area of their consolidation. The richest concentrations of finds are in the forest zone of eastern Europe, in the Upper Volga and Kama basins (Fig. 12). However isolated finds of Seima-Turbino type are known as far as the Baltic and even Moldova (the famous Borodino hoard). The distance between the westernmost and easternmost finds of Seima-Turbino metal products - from China to Fenno-Scandia - exceeds $6000 \mathrm{~km}$ !

Both waves - western and eastern - seem to move in opposite directions, and it is obvious that they followed parallel lines. Abashevo-Sintashta sites mainly occur in the forest-steppe regions and in the extreme south of the forest zone (and are earliest in eastern Europe); east of the Urals the migration aimed at more southern regions.
The distribution of Seima-Turbino metal finds indicates that their carriers either preferred a forest zone or were compelled to move in this safer environment. Nevertheless, there are clearly certain contacts between two given waves orstreams. Some cemeteries of obviously Seima-Turbino type clearly include burials with Abashevo or Abashevo-Sintashta weapons and (occasionally) ceramics. These burials follow Seima-Turbino ritual canons: i.e., human remains were almost always absent. These cases are important for both the relative and absolute chronology of the two groups. It is remarkable, however, that AbashevoSintashta necropolises do not contain Seima-Turbino elements.

The calendar age of the Abashevo-Sintashta community is based on the analysis of 75 radiocarbon dates (Fig. 15). The frequency for the three cultures that comprise the community is uneven: Sintashta has 44 dates, Abashevo 22, and Petrovka only nine. In spite of the different number of dates available for each, their respective $68 \%$ summed probabilities $(68 \%)$ coincide with amazing precision between XXII to XVIII/XVII centuries $\mathrm{BC}$. We emphasize once again that the absence of any appreciable difference between the chronological ranges of three cultures occupying such a long distance allows us to conclude with confidence that entire Abashevo-Sintashta community moved rapidly towards the East. 




Fig. 13. Eurasian metallurgical province - copper and bronze tools and weapons of the steppe stock-breeding cultures. $\boldsymbol{A}$ - Abashevo culture (early - first - phase of province); $\boldsymbol{B}$ - Srubnaya community (second phase of province).

Only four dates are known to the author from sites of the Seima-Turbino type: one from a burial in the Satygha cemetery, in the northern taiga to the east of the Urals, and three from the recently found and investigated necropolis of Yur'ino (Ust'-Vetluga), Upper Volga basin. All four dates fall within the Abashevo-Sintashta chronological range (11). Hence, we can with confidence define the age of the Seima-Turbino phenomenon to be between XXII and XVIII/XVII centuries BC.

\section{The second phase of the Eurasian metallurgical province: stabilization of the system}

The second phase of EurAsMP development was characterized by the stabilization of the steppe belt cultures and communities. There is an appreciable unification of the major cultural features throughout the steppe belt. Across this enormous territory differences between settlements are hardly perceptible. The same must be said about the very large number of funerary sites. The ostentatious expression of the social-hierarchical posi-

(11) Because they are so few, the Seima-Turbino dates are not included in the diagrams (Fig. 15).

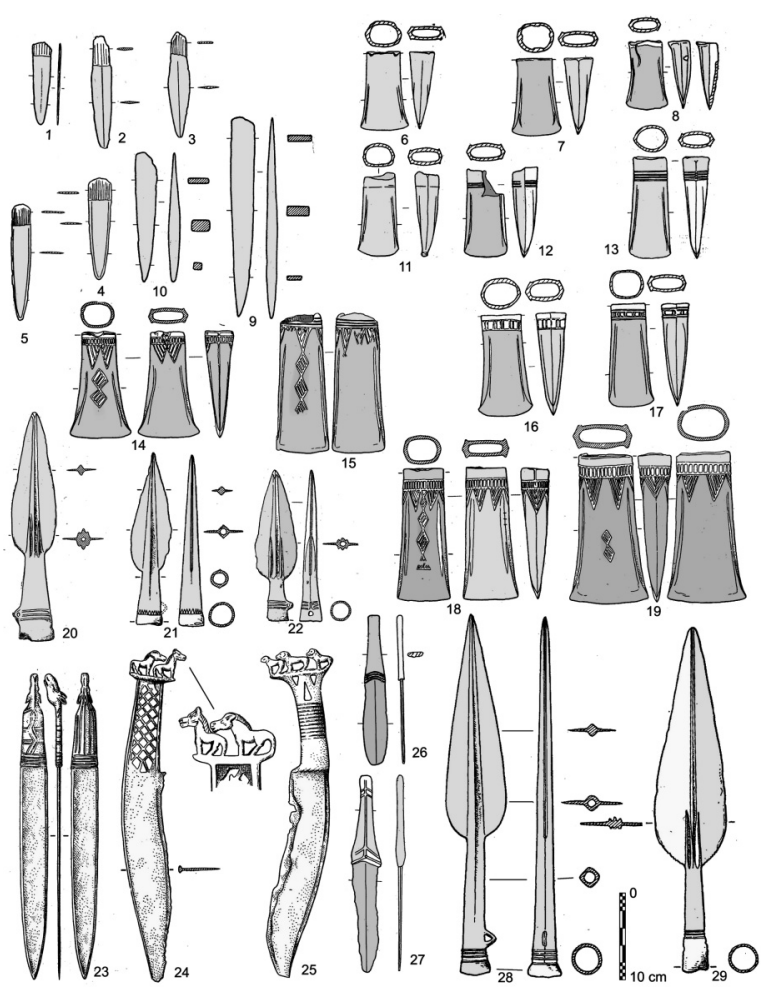

Fig. 14. Seima-Turbino transcultural phenomenon: bronze weapons and tools.

tion of the deceased that is so characteristic, say, of the first phase of the Early Bronze Age Circumpontic province, is absolutely absent. The uniform character of these cultures makes it very difficult for archeologists to define the territorial and chronological boundaries of particular communities. The result is a rather "blurred" picture.

Archaeological attention has concentrated on two giant cultural communities - Srubnaya in the west and Andronovo in the east - that dominate the appearance of the whole province (Fig. 16). Between these two communities of the second phase of the EurAsMP, the "syndrome of cultural continuity" is striking. There are extensive territories where the two blend together, in the area from the steppes and semi deserts to the north of the Caspian sea to the Southern Ural forest-steppe, for example (Fig. 16). The archaeological similarities in the steppe cultures in this time period are so great that at times archaeologists prefer to define a single, huge, uniform Srubnaya-Andronovo community.

The western (Srubnaya) archaeological community is found mainly in Eastern Europe and 


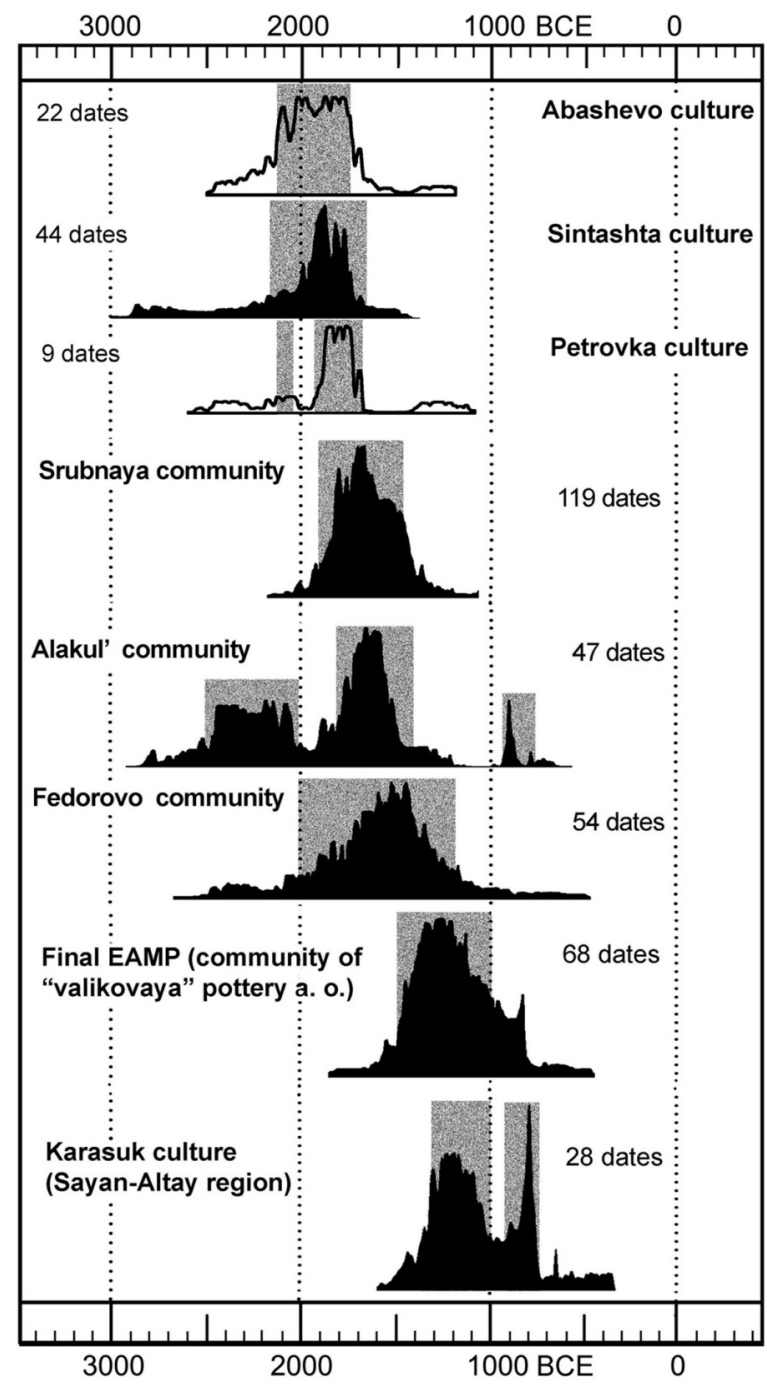

Fig. 15. Summed probabilities of radiocarbon dates of the stock-breeding archaeological cultures and communities of the Eurasian and East-Asian metallurgical provinces (Karasuk culture).

covers an area between 1.5 and 2 million $\mathrm{km}^{2}$. The eastern (Andronovo) community can be divided into two basic variants: the Alakul' and Fedorovo. Sites of the eastern community cover a territory twice as large as that of the Srubnaya culture - not less than 3 million $\mathrm{km}^{2}$.

A number of smaller, more localized archaeological groups probably should be included in the Srubnaya-Andronova circle. In southern Central Asia cultures of the Kayrak-kum and Tazabag'yab types (Chernykh 1992: 192, Fig. 67) are to some extent close to the Alakul' culture. To the north along the southern edge of the Eurasian forest zone, the Pozdniakovo and Prikazanskaya cultures are rather close to Srubnaya,

Cherkaskul' to Andronovo, and so on. Northern communities, as a rule, were marked by strong traces of steppe influence.

In the clash between the opposed AbashevoSintashta and the Seima-Turbino waves of penetration of these contrastive cultures, the former won out. In this second phase, the striking Seima-Turbino phenomenon seems to dissolve, the only remaining expression of its heritage occuring in settlements of the Samus'-Kizhirovo type in the taiga zone of Western Siberia (Chernykh and Kuz'minykh 1989: 144-162). Later, during the third phase of the EurAsMP, its features reemerge, but in this earlier second phase the western impulse of the Abashevo-Sintashta wave obviously prevailed.

The absolute chronology of the second phase is based on 222 systematized calibrated radiocarbon dates. Most of these (119) are connected with the materials of the Srubnaya community. The distribution of the sums of probabilities of this sample is immediately comprehensible (Fig. 15): the chronological range (68\% probability) of the Srubnaya community consists of the 500 years between the $\mathrm{XX}-\mathrm{XV}$ centuries $\mathrm{BC}$. The character of the distribution of the sums of probabilities for the cultures of the Andronovo community presently exhibits a less clear pattern, however. It is especially difficult to interpret the frequency diagrams for the Alakul' sites. In this case reconsideration of the whole set of the materials included in the database is certainly required. In comparison with dates of the Srubnaya community complexes the frequency diagram of distribution of the sums of probabilities for the Fedorovo culture is much less concentrated (Fig. 15). It seems most likely that these materials were strongly influenced by the "syndrome of cultural continuity" that we have discussed earlier.

\section{The third phase of the Eurasian metallurgical province: disintegration of the system}

The dynamics of EurAsMP development during its third phase of the second half of the II millennium BC (Fig. 15) entails transformation of both the Srubnaya and Andronovo communities. One extremely indistinct and amorphous cultural community in this phase is the so-called commu- 


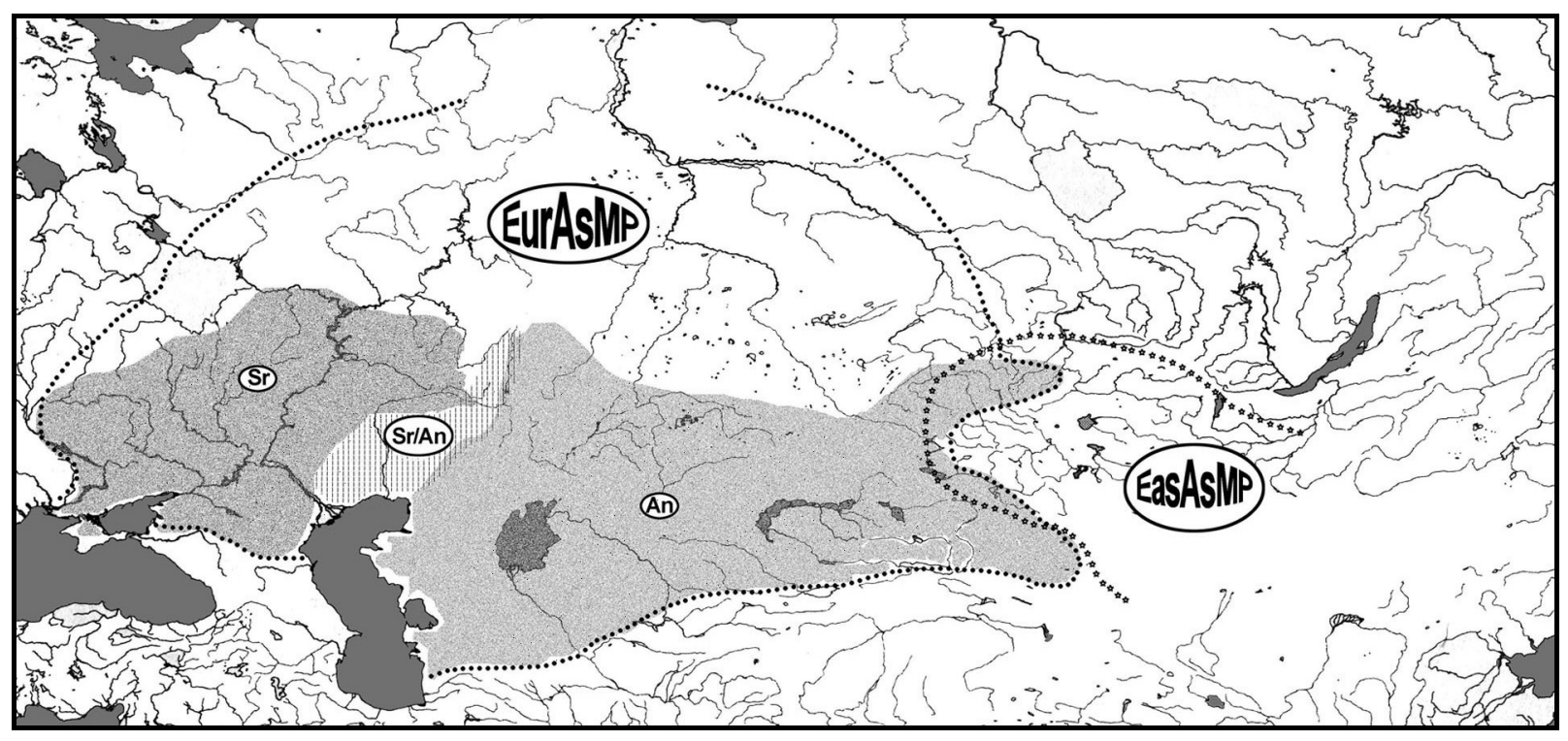

Fig. 16. Schematic map of the areas of major archaeological communities of the Eurasian metallurgical province (stabilization phase) and N-W peripheral area of the East Asian metallurgical province. $\boldsymbol{S r}$ - Srubnaya community; $\boldsymbol{A n}$ - Andronovo community; $\boldsymbol{S r} / \mathbf{A n}$ - mixed zone of Srubnaya and Andronovo communities.

nity of "valikovaya pottery". Pottery assemblages of these bloc of cultures always contain pots decorated under the rim, around the neck or around the shoulders with single applied cordons or bands (valik, after which it is named). This decoration can be found on pottery distributed over amazingly wide spaces: from the Northern Balkans and the Danube to the Altai. Distribution of this ornamental pattern probably derives from the west: in the Carpatho-Balkan region this decorative element is always present on clay vessels from the Early Bronze Age.

In this phase the steppe belt of the EurAsMP has many fewer sites - both settlement and mortuary - than in the previous phase. Most likely this was due to general transition to a mobile - nomadic and semi-nomadic - subsistence strategy.

The features of metallurgical production and metal processing characteristic of the previous period become attenuated (Chernykh 1992: 235-252) and both the eastern and western boundaries of the province become less distinct. By this time the productive centers of the mighty and striking European metallurgical province were formed (Chernykh 1992: 252-263) (12), so

(12) The western neighbor of the gigantic EurAsMP was the European MP. Distinctions between these systems are dramatic, as may be seen by a pair of the examples. Thus, 80 to that influences from the northern Balkans, the Carpathians and the Danube basin are especially strong. This is demonstrated by imports of western metal objects and also by the local production of some items copying western models. In the second half of the II millennium BC this occurs as far to the east as the Lower and Middle Volga (for example, the striking Sosnovaya Maza hoard, among others).

The eastern border of the Eurasian province in the Altai region also happens to be indefinite and ambiguous to a considerable extent. There, on the eastern periphery of the Eurasian province, a considerable number of one-bladed knives essentially alien to this province's types but characteristic of the industrial centers of the East Asian metallurgical province, have been registered.

Because sites of the final EurAsMP stage have attracted little archaeological research, the number of radiocarbon dates known and regis-

$90 \%$ of the vast amount of metal from the European province has been recovered from hoards, but the number of metal hoards known from the EurAsMP is very limited. The scale of production is also very different: the sum of all Seima-Turbino metal objects recovered from an area of a million $\mathrm{km}^{2}$ is 583 items; by contrast, one (admittedly very large) hoard from Transylvania in the European MP -Uioara de Sus- contained more than 5800 (!) objects (socketed celts, sickles, arrow heads, ornaments, etc) and weighed about 1100 (!) kg (Petrescu-Dîmboviţa 1977: 114-117) 
tered by us is only 68 (Fig. 15). Nevertheless the $68 \%$ confidence range for their summed probabilities clearly indicates that this stage covers the second half of the II millennium BC.

This chronological range can be accepted as reliable, as can be seen by comparison with the dates for the communities and cultures of the previous phase.

\section{THE THIRD STAGE OF THE "STEPPE BELT" FORMATION - THE EAST ASIAN METALLURGICAL PROVINCE}

The East Asian Metallurgical Province [EasAsMP] arises at approximately the same time as the Eurasian one, but its major features and its details have been studied much less. Here we will concentrate on the northwest sector of the EasAsMP, i.e., the Sayan-Altay mountain zone and the areas surrounding it from the northern forests to Mongolia and the Gobi desert (Fig. 16).

As mentioned above, the EasAsMP's earliest phase was associated with the striking SeimaTurbino transcultural phenomenon, and subsequently it seems to continue the Seima-Turbino traditions of metallurgy and metal processing. The most important materials characteristic of the early EasAsMP come from burials of the widely known Karasuk cultures (Chlenova 1972; Chernykh 1992: 264-271) (13). The numerous metal finds come from graves, most of which have been destroyed by recent tillage.

Between the early Seima-Turbino and later Karasuk types of metallurgy there are sufficiently striking and obvious points of interrelation (compare Figs. 14 and 17). However, attempts to reconstruct the dynamics of metallurgical development in the Sayn-Altay region encounter disappointing lacunae in the available evidence. We have shown that the aggressive wave of Seima-Turbino populations was definitely aimed westwards. We saw that its chronological range, established by contacts with the AbashevoSintashta community is the five centuries from 2200 to $1700 \mathrm{BC}$. The available radiocarbon dates for the Karasuk complexes may not be as

(13) In the cited work the EasEurMP was still alled the "Central Asian metallurgical province". The author now considers the term "East European" to be more appropriate. complete as the Abashevo-Sintashta series, but it is clear that Karasuk occupies a 500 year time span beginning 1400 or 1300 BC (Fig. 15). Thus, there are 300 or even 400 years break between the Seima-Turbino and the Karasuk ranges that are effectively blank. One would expect the appearance of new materials and the detailed study of older ones to bridge the gap.

Even more indicative is the rapid spread of Karasuk forms mainly eastward, which differed diametrically from the Seima-Turbino movement westward (Fig. 18). A rather significant number of imitations of Karasuk metal forms are currently known from Ancient China. These imitations are well represented even in the "royal" complexes of Anyang cemetery, dated on the basis of written documents to the XIII to XI centuries $\mathrm{BC}$, the period of the late Shang dynasty (Chang and Pingfang 2005: 150-176).

It is probable just at this time that active opposition between the most ancient Chinese civilizations and the steppe world begins. There is no doubt that the Karasuk antiquities were made by nomadic cattle herders: settlements of this culture are practically unknown to us.

Morphologically Karasuk differed sharply from the ancient Chinese metallurgy of Shang or Western Zhou times. The inhabitants of the Sayan-Altai always emphasized weapons: the well-known Karasuk curved one-edged knives with carved figured handles and the rarer daggers. These northern steppe (or to be more exact, taiga-steppe) forms - or rather their imitations are also present at the Shang "royal" funerary

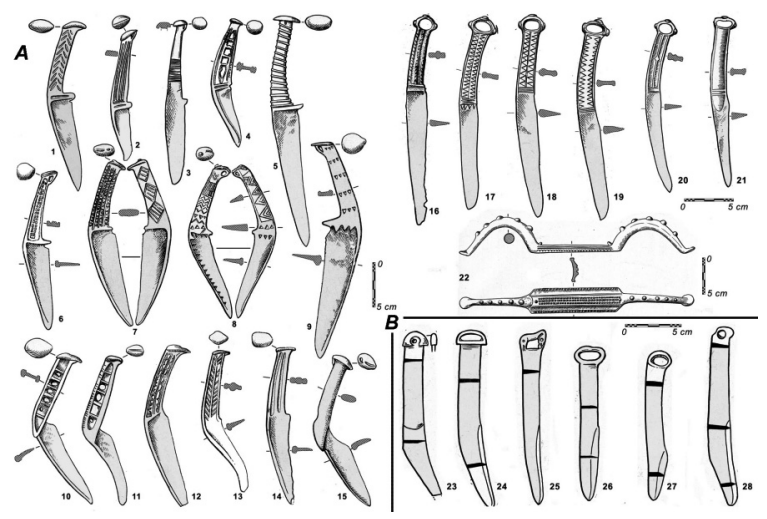

Fig. 17. Northwestern focuses (Karasuk) of the East-Asian metallurgical province: arsenical bronze producing. $\boldsymbol{A}$ - Karasuk inventory: $\boldsymbol{B}$ - Karasuk-Tagar knives (later phase). 
complexes found chiefly in the famous Anyang necropolis.

It is obvious enough that the chain of Karasuk objects (or of objects similar to Karasuk prototypes) stretched almost $3500 \mathrm{~km}$ to the East: from the Sayan-Altay region, through Xinjang (Mei 2000, 2004), Mongolia (Erdenebataar 2004), Northern China (including Inner Mongolia) to the basin of Liao He and nearly to the Liaodong gulf (Wagner 2006: 101-276). The other line of distribution of the steppe forms has a more southern or southeastern direction. Similar products are known to us from semi-desert and desert foothills of the Altun-Shan and Shanxi-Shaanxi Plateau (Fig. 16). They approach right up to the territory on the Yellow River ruled by Shang governors (Chinese Archaeology 2003: 585-590).

All the same, we must note one rather essential difference between Karasuk and ancient Chinese metalwork. The lion's share of the bronzes produced by Shang and Western Zhou metallurgists was directed towards sacral purposes connected, first of all, with diverse ritual and magical ceremonies. The Karasuk metallurgy is incomparably more rational and easier to understand. It was oriented first of all to the creation of metal weapons. The decoration of the curved knives with figures of animals or certain ornamental patterns did not change the basic character of this northern handicraft. Plates, pendants and even the mysterious "horse yokes" were certainly subordi- nate to weapons in the production of the steppe founders and smiths.

\section{BRIEF CONCLUDING REMARKS}

Again we return to the idea stated earlier: by the second half of the II millennium BC the formation of the cattle breeding cultures of the huge Eurasian steppe belt had been completed. This process was difficult and long; it was characterized by surprisingly powerful territorial "jumps" and by sudden slowing downs. At this time the latitudinal structure of the basic categories or types of Eurasian cultures was formed.

This structure determined many major historical processes into modern times. The steppe belt served as a watershed between the southern and northern communities of the giant Eurasian continent.

Historical processes often determined the origin, existence and destruction of numerous communities and populations. By the mid-second millennium we can also distinguish a longitudinal profile within the Eurasian world. Such a watershed quite probably had an effect on the formation of two models of metallurgy - the West-Eurasian and the East-Eurasian ones. The formation of two different worlds can be glimpsed behind these models. And the great belt of steppe cultures often

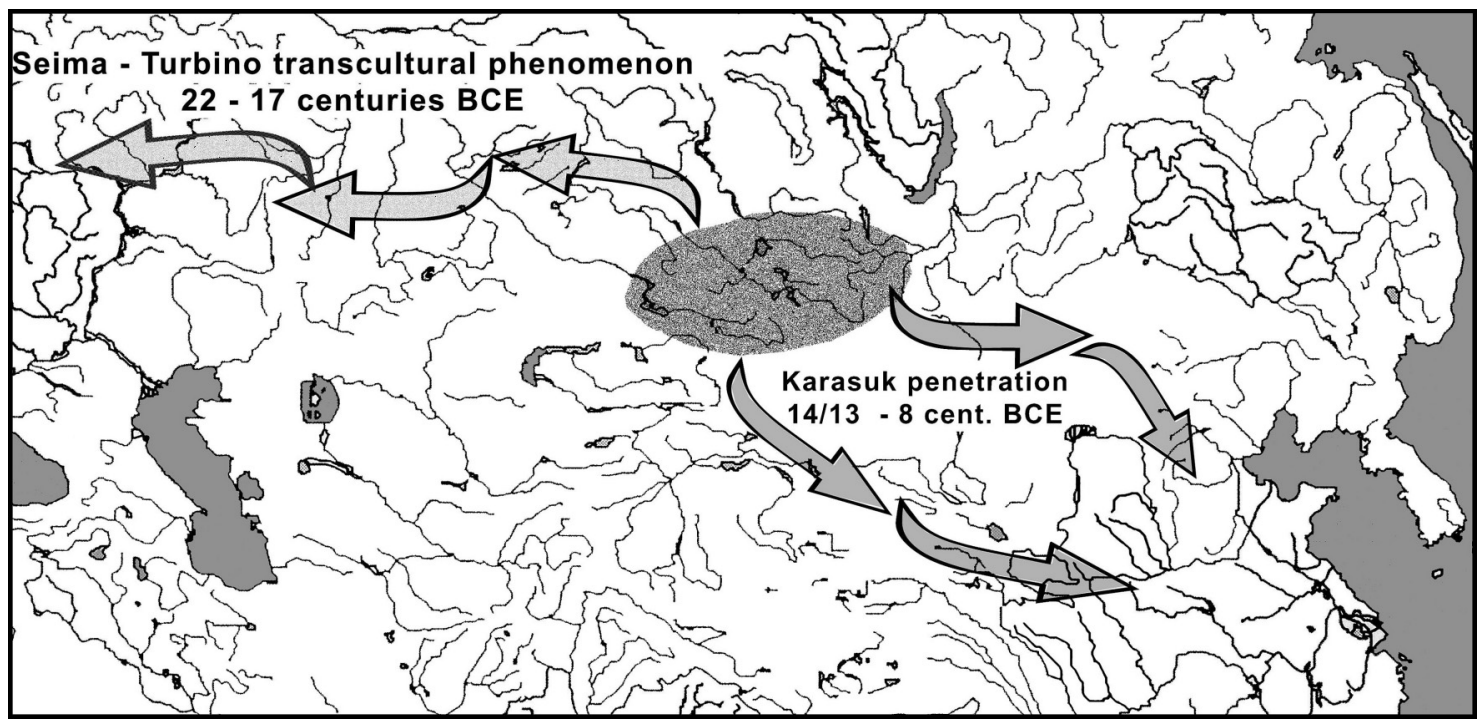

Fig. 18. General ways of diffusion and penetration of Seima-Turbino and Karasuk metal forms. 
played the role of a peculiar bridge connecting two these rather dissimilar worlds.

And finally one last point. Ordering into a single system a huge series of the calibrated, statistically processed radiocarbon dates requires us to make rather serious revisions in the general picture of not only the absolute, but also the relative chronology of a variety of Eurasian cultures and communities. Many archeological postulates and seemingly harmonious axioms concerning basic aspects of relative chronological scales are cast into doubt. However it is clear that discussion of these most complicated problems cannot be addressed in these brief concluding remarks. They will certainly demand further specialized and broad research.

\section{BIBLIOGRAPHY (14)}

Antipina, E.E. and Morales, A. 2005: “'Cowboys' of East European Steppe in the Late Bronze Age". OPUS: Mezhdistsiplinarnye issledovaniia v arkheologii 4: 45-49 (in English and Russian).

Arkheologiia Ukrainskii SSR 1985: ... I. Naukova dumka. Kiev.

Bar-Adon, P. 1980: The cave of the Treasures. The Israeli Exploration Society. Jerusalem $\left(1{ }^{a}{ }^{\mathrm{e}}\right.$ ed. in Hebrew 1971).

Černych. E.N. 1991: "Frühestes Kupfer in der Steppenund Waldsteppenkulturen Osteuropas". J. Lichardus (Hrg.): Die Kupferzeit als Historische Epoche. Dr. R. Habelt GmBH. Bonn: 581-592.

Comşa, E. 1991: "Cucuteni und Nordpontische Verbindungen". In J. Lichardus (Hrg.): Die Kupferzeit als historische Epoche. Dr. Rudolf Habelt GMBH. Bonn: 85-88.

Chang, Kwang-chih and Pingfang, X. (eds.) 2005: The Formation of Chinese Civilization. An Archaeological Perspective. Yale University Press and New World Press. Bejing and New Haven and London.

Chernij, E.N. 1993a: "Ritmo y modelos de las destrucciones tecnológicas y culturales fundamentales a partir del descubrimiento del metal". In M.'I. Martinez Navarrete (coord.): Teoría y práctica de la Prehistoria: perspectivas desde los extremos de Europa. Universidad de Cantabria, CSIC. Santander: 275-300 (in Spanish and English).

(14) Editor's note: Transliteration Schemes for Non-Roman Scripts from 1997 edition of the ALA-LC Romanization Tables, approved by the Library of Congress and the American Library Association http:/www.loc.gov/catdir/cpso/roman.html. We would like to thank Antonio Gilman for his meticulous editing of the original text and Philip L. Kohl for his final review.
Chernij, E.N. 1993b: "Laboratorio de métodos científico-naturales. Instituto de Arqueología. Academia de Ciencias de Rusia, Moscú". In M.'I. Martinez Navarrete (coord.). Teoría y práctica de la Prehistoria: perspectivas desde los extremos de Europa. Universidad de Cantabria, CSIC. Santander: 257-273 (in Spanish and English).

Chernij E.N.; Avilova L.I.; Bartseva T.B.; Orlovskaia L.B. y Teneishvili T.O. 1990: "El sistema de la Provincia Metalúrgica Circumpóntica". Trabajos de Prehistoria 4: 63-101.

Chernykh, E.N. 1992: Ancient Metallurgy in the USSR. The Early Metal Age. Cambridge University Press. Cambridge.

Chernykh, E.N. (red.) 2002: Kargaly II. Iazyki slavianskoi kul'tury. Moskva.

Chernykh, E.N. (red.) 2005: Kargaly IV. Iazyki slavianskoi kul'tury. Moskva.

Chernykh, E.N. (red.) 2007a: Kargaly. Fenomen i paradoksy razvitiia. Iazyki slavianskoi kul'tury. Moskva.

Chernykh, E.N. 2007b: "Drevniaia metallurgiia evraziiskikh stepei i Kitaia: problema vzaimodeistvii". Severnaia Evraziia v antropogene: chelovek, paleotekhnologii, geoekologiia, etnologiia i antropologiia II. Izdatel'stvo 'Ottisk'. Irkutsk.

Chernykh, E.N.; Avilova, L.I. and Orlovskaia, L.B. 2000: Metallurgical province and radiocarbon chronology. Institut Arkheologii Rossiiskaia Akademiia Nauk. Moskva.

Chernykh, E.N.; Avilova, L.I.; Orlovskaia, L.B. and Kuz'minykh, S.V. 2002: "Metallurgiia v Tzirkumpontiiskom areale: ot edinstva k raspadu". Rossiskaia arkheologiia 1: 5-23.

Chernykh, E.N. and Kuz'minykh, S.V. 1989: Drevniaia metallurgiia Severnoi Evrazii (seiminsko-turbinskii fenomen). Nauka. Moskva.

Chinese Archaeology 2003: ... Xia and Shang. Archaeological Monograph Series, Type A, No. 29. China Social Sciences Press. Beijing (In Chinese).

Chlenova N.L. 1972: Khronologiia pamiatnikov karasukskoi epokhi. Nauka. Moskva.

Díaz-del-Río, P.; López García, P.; López Sáez, J.A.; Martinez Navarrete, M.a.I.; Rodríguez Alcalde, A.L.; Rovira Llorens, S.; Vicent García, J.M. and Zavala Morencos, I. de 2006: "Understanding the productive economy during the Bronze Age through archaeometallurgical and palaeoenvironmental research at Kargaly (Southern Urals, Orenburg, Russia)". In D.L. Peterson, L.M. Popova and A.T. Smith (eds.): Beyond the Steppe and the Sown: Proceedings of the 2002 University of Chicago Conference on Eurasian Archaeology. Colloquia Pontica 13. Brill. Leiden: 347-361.

Dzhaparidze, O.M. 1998: K etnokul'turnoi istorii gruzinskikh plemen $v$ III tysiacheletii do n.e. (Ranne-

T. P., 65, N. ${ }^{\circ}$ 2, Julio-Diciembre 2008, pp. 73-93, ISSN: 0082-5638

doi: $10.3989 /$ tp.2008.08004 
jurganskaia kyl'tura). Izdatel'stvo Tbilisskogo Universiteta (In Georgian).

Erdenebataar, D. 2004: "Burial Materials Related to the History of the Bronze Age in the Territory of Mongolia". In K.M. Linduff (ed.): Metallurgy in Ancient Eastern Eurasia from the Urals to the Yellow River. The Edwin Mellen Press Ltd. New York: 189-223.

Ecsedi, I. 1979: The people of the Pit Grave cultures in Eastern Hungary. Fontes Archaeologici Hungariae. Budapest.

Formozov, A.A. 1965: Kamennyi vek $i$ eneolit Prikuban'ia. Nauka. Moskva.

Gorodtsov, V.A. 1905: “Rezul'taty arkheologicheskikh ussledovanii v Iziumskom uezde Kharkovskoi gubernii 1901 goda". Trudy XII Arkheologicheskogo $s$ 'ezda I. Sankt-Peterburg.

Gorodtsov, V.A. 1907: "Rezul'taty arkheologicheskikh ussledovanii v Bakhmutskom uezde Ekaterinoslavskoi gubernii 1903 goda". Trudy XII Arkheologicheskogo s'ezda I. Sankt-Peterburg.

Gorodtsov, V.A. 1916: “Kyl'tury bronzovoi epokhi a Srednei Rossii". Otchety istoricheskogo myzei za 1919 god. Moskva.

Gumilev, L.N. 1989: Drevniaia Rus' $i$ Velikaia step'. Mysl'. Moskva.

Iurchenko, A.G. 2002: "Ékspozitsiia". Khristianskii mir $i$ "Velikaia Mongolskaia imperiia. Materialy frantsiskanskoi missii 1245 g. Evraziia. Sankt-Peterburg.

Jovanović, B. 1979: "Stepska kultura u enolitskom periodu Jugoslavije”. Praistorija Jugoslavenskih zemalja. Eneolit. Akademija nauka i umetnosti Bosne i Hercegovine. Sarajevo: 381-396.

Kohl, Ph. 2007: The Making of Bronze Age Eurasia. Cambridge University Press. Cambridge.

Kotova, N.S. 2002: Neolitizatsiia Ukrainy. Shliakh. Lugansk.

Lebedeva, E.Yu. 2005: "Archaeobotany and Study of the Bronze Age Agriculture in Eastern Europe". OPUS: Mezhdistsiplinarnye issledovaniia $v$ arkheologii 4: 50-68 (in English and Russian).

Petrescu-Dîmboviţsa, M. 1977: Depozitele de Bronzuri din România. Editura Academiei RSR. Bucureşti.

Mei, J. 2000: Copper and Bronze Metallurgy in Late Prehistoric Xinjiang. Its cultural context and rela- tionship with neighbouring regions. BAR International Series 865. Oxford.

Mei, J. 2004: "Metallurgy in Bronze Age Xinjang and its Cultural Context". In M. Linduff (ed.): Metallurgy in Ancient Eastern Eurasia from the Urals to the Yellow River. The Edwin Mellen Press Ltd. New York: 173-188.

Morales, A. and Antipina, E. 2003: "Srubnaya Faunas and Beyond: A Critical Assessment of the Archaeozooological Information from the East European Steppe". In M. Levine, C. Renfrew and K. Boyle (ed.): Prehistoric steppe adaptation and the horse. McDonald Institute Monographs 9. Cambridge: $329-351$.

Munchaev, R.M. 1975: Kavkaz na zare bronzovogo veka. Hayka. Moskva.

Munchaev, R.M. 1994: "La Edad del Bronce Antiguo en el Caúcaso". In 6 Coloquio hispano - ruso de Historia. Fundación Cultural Banesto, CSIC. Madrid: 93-121.

Rassamakin, Ju.Ja. 2004: Die nordpontische Steppe in der Kupferzeit. Gräber aus der Mitte des V. Jts. Bis Ende des 4. Jts. V. Chr. Archäologie in Eurasien 17. Verlag Philipp Von Zabern. Mainz.

Rezepkin A.D. 2000: Das frühbronzezeitliche Gräberfeld von Klady und die Majkop-Kultur in Nordwestkaukasien. Archäologie in Eurasien 10. Verlag Marie Leidorf GmbH. Rahden/Westf.

Ryndina, N.V. 1998: Drevneishee metalloobrabatyvaiushchee proizvodstvo Iugo-Vostochnoi Evropy. Editorial URSS. Moskva.

Telegin D.J. 1991: “Gräberfeld des Mariupoler Typs und der Srednij Stog-Kyltur in der Ukraine (mit Fundortkatalog)". En J. Lichardus (Hrg.): Die Kupferzeit als historische Epoche. Dr. Rudolf Habelt GMBH. Bonn: 55-84.

Telegin, D.Ya.; Kovaliukh, M.M.; Potekhina, I.D. y Lillie, M. 2000: "Chronology of Mariupol type cemeteries and subdivision of the Neolithic-Copper Age Cultures into periods for Ukraine". Radiocarbon and Archaeology 1, 1: 59-74. Saint Peterburg.

Wagner M. 2006: Neolithikum und Frühe Bronzezeit in Nordchina vor 8000 bis 3500 Jahren. Die nordöstliche Tiefebene (Südteil). Archäologie in Eurasien 21. Verlag Philipp von Zabern. Mainz. 